\title{
ASMENŲ, PERSIRGUSIŲ GALVOS SMEGENŲ INFARKTU, SAVARANKIŠKUMO IR PLAS̆TAKOS RAUMENŲ JËGOS POKYČIAI TAIKANT İPRASTĄ IR DIFERENCINIO MOKYMO METODIKA PAREMTĄ ERGOTERAPIJĄ
}

\author{
Viktorija Repšaite் ${ }^{1}$, Daiva Baltaduoniené ${ }^{2}$, Alfonsas Vainoras ${ }^{1}$ \\ ${ }^{1}$ Lietuvos sveikatos mokslu universitetas, ${ }^{2}$ Kauno kolegija
}

Raktažodžiai: galvos smegenų infarktas, ergoterapija, diferencinis mokymas, savarankiškumas.

\section{Santrauka}

Galvos smegenų infarktas - ūminis židininis galvos smegenų kraujotakos sutrikimas, pasireiškiantis židininiais neurologiniais simptomais, išliekančiais ilgiau kaip 24 val. nuo ligos pradžios. Ergoterapijos tikslas pacientams, patyrusiems galvos smegenų infarktą, - padèti sugrižti fizinèms, protinèms, socialinėms ir profesinėms galimybèms. Ergoterapijos tikslas pacientams, patyrusiems galvos smegenų infarktą, yra jų galimybių atgavimas, palaikymas ar sutrikimų kompensavimas tikslinga veikla, siekiant padèti savarankiškai gyventi. Diferencinio mokymo metodas - alternatyva kartotiniams judesiams. Tyrimo tikslas - ištirti savarankiškumo ir plaštakos raumenų jëgos pokyčius pacientams, persirgusiems galvos smegenų infarktu, taikant ịprastą ir diferencinio mokymo metodika paremtą ergoterapiją. Tyrime dalyvavo 27 pacientai, persirgę galvos smegenų infarktu, iš jų 9 vyrai (33,3 proc.) ir 18 moteru (66,7 proc.). Tiriamieji buvo 50 - 85 metų amžiaus (amžiaus vidurkis $72,19 \mathrm{~m} . \pm 8,02$ ). Prieš tyrimą pacientai atsitiktinès atrankos būdu buvo suskirstyti i dvi grupes: A - kontrolinè grupé, 13 pacientų $(48,1$ proc.), B - tiriamoji grupé, 14 pacientų (51,9 proc.). Pacientai reabilitacijos pradžioje ir pabaigoje ergoterapeuto buvo tiriami naudojant: dinamometrą, tirta dešinès ir kairès plaštakų raumenų jẻga, bei Tarptautinès funkcionavimo, neiggalumo ir sveikatos klasifikacijos (TFK) skyriaus Veiklos ir dalyvumo savipriežiūros testą. Kontrolinès grupès tiriamiesiems prieš ergoterapiją savipriežiūros užduočių atlikimas buvo vidutinio sunkumo, o tiriamosios grupès pacientų - vidutinio/nedidelio sunkumo. Straipsnyje pateikiami duomenys atskleidžia, jog po ergoterapijos tiriamosios grupès rezultatai statistiškai reikšmingai skyrèsi nuo kontrolinès grupès rezultatu $(p<0,05)$ : tiriamosios grupès pacientai tapo savarankiški (nebuvo sunkumų atliekant savarankiškumo užduotis), o kontrolinès grupès pacientams išliko nedidelis sunkumas atliekant savarankiškumo užduotis. Straipsnyje pateikiami duomenys ir apie tiriamosios bei kontrolinès grupių plaštakų raumenų jègos pokyčius, tačiau statistiškai reikšmingo skirtumo nenustateme: tiriamosios grupès dešinès plaštakos raumenų jèga padidejo $3,78 \mathrm{~kg}$, o kontrolinès grupès $-2,17 \mathrm{~kg}$. Tiriamosios grupès kairès rankos plaštakos raumenų jèga padidejo $2,00 \mathrm{~kg}$, o kontrolinès grupès $-2,68 \mathrm{~kg}$.

\section{Ivadas}

Galvos smegenu infarktas - ūminis židininis galvos smegenų kraujotakos sutrikimas, pasireiškiantis židininiais neurologiniais simptomais, išliekančiais ilgiau kaip 24 val. nuo ligos pradžios [2]. Lietuvoje apie 80 proc. ligonių, persirgusių galvos smegenu insultu, tampa neigaliais dèl kognityvinių, motorinių funkcijų pažeidimo, sutrikdančių jų kasdienę veiklą bei darbingumą [6]

Lietuvoje iš 10 tūkst. gyventojų insultu suserga per metus maždaug 4-5. Dažniausiai serga pavasarị ir rudenį. Insulto rizikos veiksniai yra: genetinis polinkis sirgti kraujagyslių ligomis, smegenų bei širdies ir kraujotakos ligomis, taip pat hiperlipidemija, hiperglikemija, nutukimas, arterinè hipertenzija, hipodinamija, rūkymas, emocinè itampa, stresas. Jei yra daugiau kaip du rizikos veiksniai, tikimybė susirgti insultu didesnè. Lietuvoje ši liga yra ne tik medicinos, bet ir socialinė problema, nes po insulto tik apie 20 proc. žmonių vèl būna darbingi [5].

Ergoterapija - mokslas apie sutrikusio žmogaus veiklos atgavimą ar ugdymą, siekiant gerinti jo biosocialines funk- 
cijas, ịveikiant ar mažinant negalią [5]. Ergoterapija apima kasdienę veiklą, produktyviają veiklą (darbą), laisvalaikio praleidimą. Ergoterapijos tikslas pacientams, patyrusiems galvos smegenų infarktą, - padèti sugrižti paciento fizinèms, protinèms, socialinèms ir profesinèms galimybėms. Nuo pat ligos pradžios siekti, kad pacientas būtų kiek įmanoma mažiau priklausomas kasdienèje veikloje $[3,4]$.

Diferencinio mokymo metodas - alternatyva kartotiniams judesiams. Diferencinio mokymo metodas vystomas remiantis neurofiziologiniais ir dinaminių sistemų tyrinèjimais [8]. Diferencinis mokymas aktyvuoja žmogaus judamojo elgesio svyravimus, kad paskatintų besimokančiojo saviorganizaciją. Taip besimokantysis atranda individualu judesių ir jo mokymosi būdus. Todèl svyravimus reikia ne slopinti, o stiprinti, kad ligonis atrastų individualias galimų sprendimų erdves. Šiam tikslui pasiekti besimokantysis išmokimo fazès metu susiduria su ịvairiais pratimais, išplèsiančiais galimų užduoties sprendimų ribas. Diferencinis mokymas apima dalyvaujančių sąnarių judejjimą, judesio geometriją, greiti, akceleraciją, laiką ir ritmą, „klasikinių“ judesio klaidų variacijas, ịrangos ir aplinkos variacijas ir visų variantų derinius be jokių judesio pakartojimų [10]. Kitaip tariant, tam tikrą ịūdị reikia treniruoti daugeliu skirtingų būdų, kad būtų atrastas individualus ir optimaliausias besimokančiajam būdas. Kadangi diferencinès treniruotès metu pratimai yra nekartojami, pasiekiamas adekvatesnis prisitaikymas prie nuolat kintančių sąlygų $[1,7,8]$.

Tikslas - ištirti savarankiškumo ir plaštakos raumenų jëgos pokyčius pacientams, persirgusiems galvos smegenų infarktu, taikant ịprastą ir diferencinio mokymo metodika paremtą ergoterapiją.

\section{Tyrimo metodai}

Tyrimas atliktas Všt Kauno klinikinès ligoninès Fizinès medicinos ir reabilitacijos skyriuje.

Prieš tyrimą pacientai, persirgę galvos smegenų infarktu ir lankantys ergoterapijos užsièmimus, pagal medicininius dokumentus (trumpa protinès būklès tyrimą ir Barthel indeksą) atsitiktinès atrankos būdu suskirstyti ị dvi grupes: A - kontrolinè grupè, B - tiriamoji grupè.

Kontrolinei grupei (A grupei) sudaryta standartizuota programa, pritaikyta individualiai iprastinei ergoterapijai (5 k./sav.), paremtai pratimų kartojimu pacientams, persirgusiems galvos smegenų infarktu, stengiantis atstatyti esamus asmens rankos funkcijos ir savarankiškumo sutrikimus. Šią programą sudaro pratimai ir priemonès viršutinès galūnès raumenų stiprinimui, judesių amplitudès lavinimui, smulkiosios motorikos ir judesių koordinacijos gerinimui.

Tiriamajai grupei (B grupei) sudaryta standartizuota, pritaikyta individuali ergoterapijos programa, sudaryta iš iprastinès ergoterapijos, paremtos pratimų kartojimu (3 k./ sav.) ir ergoterapijos, paremtos diferencinio mokymo metodika ( $2 \mathrm{k} . / \mathrm{sav}$.$) , pacientams, persirgusiems galvos smegenų$ infarktu, siekiant atstatyti rankos funkcijos ir savarankiškumo sutrikimus. Šią programą sudaro ịprastinès ergoterapijos priemonès, tačiau pratimai atliekami kiekvieną kartą keičiant atlikimo sąlygas, nekartojant veiksmo (pratimo) atlikimo situacijos, keičiant pratimo atlikimo aplinkybes, kaskart stengiantis pagristai motyvuoti pacientą.

Visiems tiriamiesiems ergoterapijos užsiëmimai vyko 5 kartus per savaitę. Užsièmimo trukmè - 30 min. Reabilitacijos trukmè 32 dienos. Pacientams reabilitacijos metu buvo taikoma ergoterapija, kineziterapija, fizioterapija, socialinio darbuotojo ir psichologo konsultacijos, medikamentinis gydymas.

Pacientams prieš ergoterapiją ir po ergoterapijos buvo matuojama plaštakos raumenų jèga $(\mathrm{kg})$, pacientai buvo vertinami Tarptautinès funkcionavimo, neigalumo ir sveikatos klasifikacijos (TFK) skyriaus Veiklos ir dalyvumo savipriežiūros testu. Iš šio testo naudojome tik prausimąsi ir maudymąsi, kūno dalių priežiūrą bei rengimąsi. Šios dalys sudarytos iš atskirų savipriežiūros elementų. Vertinant pacientą, buvo taikoma skalè: 0 - nèra sunkumo, 1 - nedidelis sunkumas, 2 - vidutinis sunkumas, 3 - didelis sunkumas, 4 - visiškas sunkumas.

\section{Rezultatai ir jų aptarimas}

Tyrime dalyvavo 27 asmenys: 9 vyrai (33,3 proc.) ir 18 moterų (66,7 proc.) persirgę galvos smegenų infarktu ir stacionarizuoti i Všt Kauno klinikinès ligoninès Fizinès medicinos ir reabilitacijos skyrių nuo $2013 \mathrm{~m}$. rugsėjo mén. $3 \mathrm{~d}$. iki $2013 \mathrm{~m}$. gegužès mèn. $31 \mathrm{~d}$. Tiriamieji buvo 50 - 85 amžiaus, (amžiaus vidurkis 72,19 $\pm 8,02$ ).

Prieš tyrimą pacientai atsitiktinès atrankos būdu buvo suskirstyti ị dvi grupes: A - kontrolinè grupè, 13 pacientų (48,1 proc.), B - tiriamoji grupé, 14 pacientų (51,9 proc.).

Tiriamieji buvo vertinami Tarptautinès funkcionavimo, neigalumo ir sveikatos klasifikacijos (TFK) skyriaus Veiklos ir dalyvumo savipriežiūros testu. Kontrolinès ir tiriamosios grupès pacientams prieš ergoterapiją buvo didelis sunkumas atliekant šias savipriežiūros užduotis: maudymąsi, nusišluostymą, rankų, kojų nagų priežiūrą, apsiavimą. Kontrolinès grupės tiriamiesiems po ergoterapijos šias savipriežiūros užduotis atlikti išliko vidutinis sunkumas, o tiriamosios grupès pacientams - nedidelis sunkumas, tačiau statistiškai reikšmingo skirtumo nenustatėme.

Atliekant visas kitas savipriežiūros užduotis (kūno dalių prausimas ir plovimas, odos, dantų, plaukų priežiūra, drabužių užsivilkimas, drabužių nusivilkimas, nusiavimas, tinkamos aprangos pasirinkimas) kontrolinès grupès tiria- 


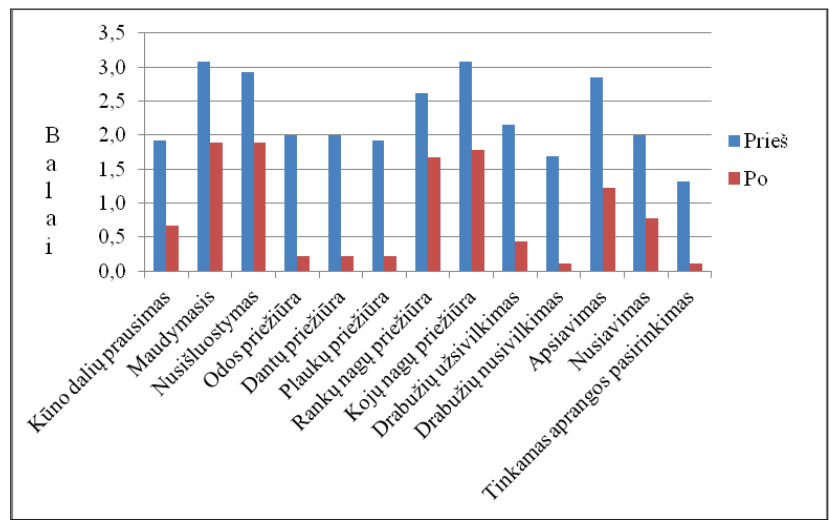

1 pav. Kontrolinès grupés savipriežiūros testo rezultatai prieš ir po ergoterapijos

miesiems prieš ergoterapiją atlikti buvo vidutiniškai sunku, tiriamosios grupès pacientams - vidutinis/nedidelis sunkumas. Po ergoterapijos tiriamosios grupés rezultatai statistiškai reikšmingai skyrèsi nuo kontrolinès grupès rezultatu $(p<0,05)$ : tiriamosios grupès pacientai tapo savarankiški (nebuvo sunkumų atliekant savarankiškumo užduotis), o kontrolinès grupès pacientams išliko nedidelis sunkumas atliekant savarankiškumo užduotis (1,2 pav.).

Visiems pacientams prieš ergoterapiją ir po jos buvo matuojama dešinès ir kairès plaštakų raumenų jèga. Kontrolinei (A) grupei dešinès plaštakos raumenu jèga prieš ergoterapiją buvo $21,08 \mathrm{~kg}$, po ergoterapijos $-23,25 \mathrm{~kg}$. Kairès plaštakos raumenu jèga prieš ergoterapiją buvo 19,15 $\mathrm{kg}$, po ergoterapijos $-21,83$.

Tiriamajai (B) grupei dešinès plaštakos raumenu jèga prieš ergoterapiją buvo $18,36 \mathrm{~kg}$, po ergoterapijos - 22,14 kg. Kairès plaštakos raumenų jèga prieš ergoterapiją buvo $21,57 \mathrm{~kg}$, po ergoterapijos - 23,57.

Gauti rezultatai rodo, kad tiriamosios grupès dešinès plaštakos raumenų jèga padidejo $3,78 \mathrm{~kg}$, o kontrolinès grupès $-2,17 \mathrm{~kg}$. Tiriamosios grupès kairès rankos plaštakos raumenų jèga padidèjo $2,00 \mathrm{~kg}$, o kontrolinès grupès $-2,68 \mathrm{~kg}$, tačiau statistiškai reikšmingo skirtumo nenustatème.

\section{Išvados}

1. Pacientų, patyrusių galvos smegenų infarktą, savarankiškumas taikant ịprastą ergoterapiją kartu su ergoterapija, paremta diferencinio mokymo metodika, statistiškai reikšmingai pagerèjo lyginant su pacientų, kuriems buvo taikoma tik ịprastinė ergoterapija.

2. Pacientų, patyrusių galvos smegenų infarktą, kuriems buvo taikoma iprasta ergoterapija kartu su ergoterapija, paremta diferencinio mokymo metodika, dešinès

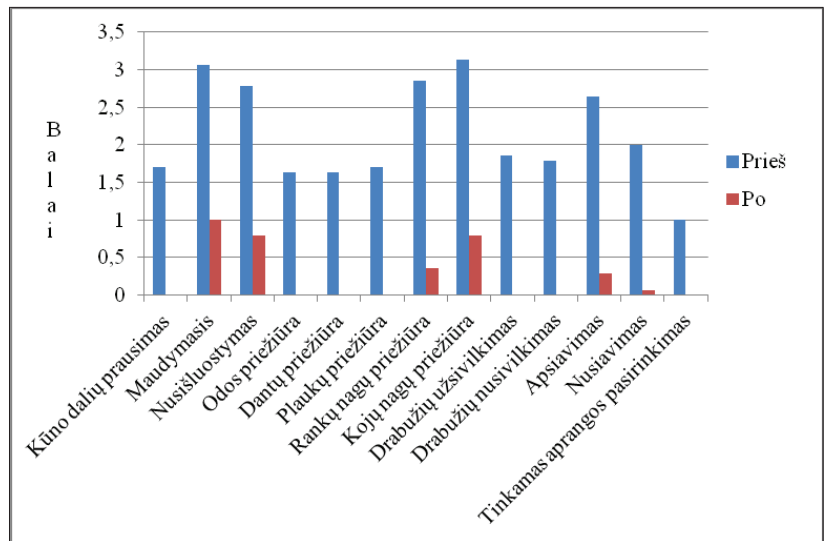

2 pav. Tiriamosios grupès savipriežiūros testo rezultatai prieš ir po ergoterapijos

plaštakos raumenų jèga padidèjo $3,78 \mathrm{~kg}$, kairès - 2,00 kg.

3. Pacientų, patyrusių galvos smegenų infarktą, kuriems buvo taikoma ịprasta ergoterapija, dešinès plaštakos raumenų jèga padidejjo $2,17 \mathrm{~kg}$, kairès $-2,68 \mathrm{~kg}$.

\section{Literatūra}

1. Beckmann H, Schöllhorn WI. Differencial Training in Soccer. In: Schöllhorn WI, Bohn C, Jäger JM, Schaper H, Alichmann M. European Workshop on Movement Science. Köln: Sport und Buch Straub; 2003; 68.

2. Budrys V. Klinikinè neurologija. Vilnius, 2009; 89.

3. Krakauer JW. Motor learning: its relevance to stroke recovery and neurorehabilitation. Current Opinion in Neurology 2006; 19:84 - 90.

4. Kriščiūnas A., Kerpè R., Kimtys A. ir kt. Ergoterapija. 2008; 15:119-120.

5. Petruševičienė D., Kriščiūnas A. Ligonių, sirgusių galvos smegenų insultu, ergoterapija. Medicina, 2003; 11(39)39:10651070.

6. Petruševičienè D., Kriščiūnas A. Veiksniai, turintys įtakos sergančiujų galvos smegenų insultu ergoterapijos efektyvumui. Medicina, 2005; 41(4):320-324.

7. Savelsbergh GJP, Kamper WJ, Rabius J, De Koningi JJ, Schöllhorn WI. A new method to learn to start in speed skating: A differencial learning approach. J Sport Psychol 2010; 41:415 $-427$.

8. Schöllhorn WI, Beckmann H, Davids K. Exploiting systems fluctuations. Differential training in physical prevention and rehabilitation programs for health and exercise. Medicina, 2010; 46(6):365- 73 .

9. Schöllhorn WI, Oelenberg M, Michelbrink M. Can mental training enhance the learning effect after differencial training? A Tennins Serve Task. In: Theodorakis Y, Goudas M, Papaioannou A, editors. Proceedings of the $12^{\text {th }}$ Eoropean Congress of Sport Psychology. Halkidiki: Fepsac; 2007; 241. 
10. Schöllhorn WI, Beckmann H., Janssen D., Drepper J. Stochastic perturbation in athletics field events enhance skill acquisition. 2010; 69-82.

INDEPENDENCE AND HAND MUSCLE FORCE CHANGES OF THE PERSONS AFTER A STROKE USING CONVENTIONAL AND OCCUPATIONAL THERAPY BASED ON DIFFERENTIAL LEARNING METHOD

V. Repšaitè, D. Baltaduonienė, A. Vainoras

Key words: stroke, occupational therapy, differential learning, independence.

Summary

A stroke is an acute focal cerebral circulatory disorder characterized by focal neurological symptoms persisting longer than 24 hours from the onset of the disease. The goal of the occupational therapy in patients who have suffered a stroke is to help return the patient's physical, mental, social and professional abilities. The differential learning method is an alternative to repeated movements. The aim of the research is to explore the independence and hand muscle force changes of the persons after a stroke using conventional and occupational therapy based on differential learning method. The study involved 27 patients who suffered a stroke, 9 of which were men (33.3 percent) and 18 women (66.7 percent). The age group was between 50 and 85 (average age $72.19 \pm 8.02$ ). Prior the study patients were randomly divided into two groups:
A - the control group, 13 patients (48.1 percent), B - study group, 14 patients (51.9 percent). At the beginning and the end of the rehabilitation patients were examined by the occupational therapist using dynamometer (left and right hand muscle strength was tested) and the test of Self-observation (International Functioning, Disability and Health classification (ICF) chapter).

Before the occupational therapy the control group patients had moderate difficulty in performing self-observation tasks, the study group patients had medium / low difficulty. The findings presented in the article revealed that after the occupational therapy, the results of the study group were statistically significantly different from the results of the control group $(p<0.05)$ : the study group patients became independent (had no difficulty to perform the independence tasks), while the control group patients still had low difficulty.

This paper also presents the data about the hand muscle power changes of the study and control groups, but statistically significant difference was not found: the right hand muscle strength of the study group increased by $3.78 \mathrm{~kg}$ and of the control group by $2.17 \mathrm{~kg}$. The left hand muscle strength of the study group increased by $2.00 \mathrm{~kg}$ and of the control group by $2.68 \mathrm{~kg}$.

Correspondence to: daiva.baltaduoniene@go.kauko.lt

Gauta 2013-07-08 